\title{
Evaluation of biohydrogen production from glucose and protein at neutral initial $\mathrm{pH}$
}

\author{
Benyi Xiao, Yunping Han, Junxin Liu* \\ Research Center for Eco-Environmental Sciences, Chinese Academy of Sciences, Beijing 100085, PR China
}

\section{A R T I C L E I N F O}

Article history:

Received 17 November 2009

Received in revised form

18 March 2010

Accepted 18 March 2010

Available online 24 April 2010

Keywords:

Biohydrogen production

Evaluation

Glucose

Neutral initial $\mathrm{pH}$

Protein

\begin{abstract}
A B S T R A C T
Organic wastes are considered as potential substances for economical biohydrogen production, because the carbohydrate and protein are main components. Previous investigations indicate that an optimum hydrogen production appear in acidic conditions to carbohydrates, or in alkali condition to protein. However, in practice, the treatment of these organic wastes by anaerobic fermentation usually carries out at neutral $\mathrm{pH}$ condition, in which biohydrogen production is only a middle process. So, the purpose of this paper is to evaluate the biohydrogen production at neutral $\mathrm{pH}$ condition from carbohydrates or protein. Batch tests were conducted to investigate the differences in biohydrogen production by anaerobic fermentation at neutral initial $\mathrm{pH}$ using carbohydrate and protein (glucose and peptone) as the sole carbon source. The experimental results showed that the maximal hydrogen yields of two substrates were about $0.14 \mathrm{ml} \mathrm{H}_{2} / \mathrm{mg}$ glucose and $0.077 \mathrm{ml}$ $\mathrm{H}_{2} / \mathrm{mg}$ protein, respectively, at neutral initial $\mathrm{pH}$. Although the hydrogen yields of glucose is far greater than that of protein at neutral $\mathrm{pH}$, they were lower than previous results of hydrogen production in acidic condition to carbohydrate or in alkali condition to protein. This result shows that the neutral $\mathrm{pH}$ is not an optimal condition for biohydrogen production. In this experiment of biohydrogen production, a phenomenon has been observed that the hydrogen production and hydrogen consumption occurred simultaneously in the fermentation of protein, whereas the hydrogen production occurred only in the fermentation of glucose. Furthermore, the different evaluation of the main components of the organic liquid by-products produced by fermentation of each substrate implied that the biohydrogen production pathways of these two substrates were different. Molecular analysis indicated that the dominant microorganisms during the anaerobic fermentation of these two substrates are greatly different.
\end{abstract}

(c) 2010 Professor T. Nejat Veziroglu. Published by Elsevier Ltd. All rights reserved.

\section{Introduction}

Hydrogen is regarded as an optimal energy carrier and fuel and it has become a topic of intensive research efforts worldwide. Due to utilization of renewable energy resources and operation at ambient temperature and atmospheric pressure, biological hydrogen production is becoming an important method of fuel production and attracting the attention of many researchers. Due to its environmental friendliness, biohydrogen production from organic wastes has been attracted increased attention $[1,2]$. Biohydrogen production has been evaluated in many organic wastes, including waste molasses [3], dairy wastewater [4], sewage sludge [5,6] and so on. The hydrogen yields from these wastes differ due to their different organic composition

\footnotetext{
* Corresponding author. Tel./fax: +8610628 49133.

E-mail address: Jxliu@rcees.ac.cn (J. Liu).

0360-3199/\$ - see front matter @ 2010 Professor T. Nejat Veziroglu. Published by Elsevier Ltd. All rights reserved. doi:10.1016/j.ijhydene.2010.03.084
} 
and the primary organic components in these wastes are usually carbohydrates and/or proteins (Table 1). For example, Guo et al. [3] obtained a hydrogen yield of $3.47 \mathrm{~mol} \mathrm{H}_{2} / \mathrm{mol}$ sucrose from molasses (a carbohydrate-rich wastewater), while Cai et al. [6] found that a hydrogen yield of $16.6 \mathrm{ml} \mathrm{H}_{2} / \mathrm{g}$ DS could be obtained from alkali pre-treated sludge (a protein-rich waste) under an initial $\mathrm{pH}$ of 11.

Although the previous studies found that the $\mathrm{pH}$ is an important influence factors of biohydrogen production and the optimal $\mathrm{pH}$ of biohydrogen production from carbohydrate is acidic $\mathrm{pH}$ (about 4.5-6.0) [1,2] and that from protein is alkaline $\mathrm{pH}$ (about 8.5-10) [6,9], the traditional treatment of these organic wastes by anaerobic fermentation usually carries out at neutral $\mathrm{pH}$ condition, in which biohydrogen production is only a middle process. Additionally, the initial $\mathrm{pH}$ of these wastes and wastewater usually is neutral $\mathrm{pH}$ and controlling $\mathrm{pH}$ at acidic $\mathrm{pH}$ or alkaline $\mathrm{pH}$ will increase the cost of anaerobic fermentation and the requirement of reactor on acid-resistant and alkaline-resistant. So, the study about biohydrogen production from organic wastes at neutral initial $\mathrm{pH}$ is important for its application.

Since carbohydrate and protein are main components of these organic wastes, it would be very helpful to study the processes and differences in biohydrogen production at neutral initial $\mathrm{pH}$ from carbohydrate and protein to understand of the biohydrogen production from these organic wastes. However, few studies are about these processes and differences. Therefore, this study was conducted to evaluate the processes and differences in the production of biohydrogen from carbohydrate and protein used as the sole carbon sources with glucose and peptone as the model compounds, respectively.

\section{Materials and methods}

\subsection{Seed microflora}

Activated sludge obtained from the aerobic tank of a municipal sewage treatment plant in Beijing, China, was used as the seed microflora after pretreatment as described below. The collected sludge was settled gravitationally for about $1 \mathrm{~h}$, after which the

\section{Table 1 - Primary organic components of some wastes.}

\begin{tabular}{|c|c|c|}
\hline Wastes & Main organic components & Ref. \\
\hline Waste molasses & $\begin{array}{l}\text { Carbohydrates } \\
\text { ( } 48 \%-58 \% \text { of dry matter) }\end{array}$ & {$[3]$} \\
\hline Waste sludge & $\begin{array}{l}\text { Proteins }(25.41 \mathrm{mg} / \mathrm{l}) \\
\text { and Carbohydrates } \\
(18.72 \mathrm{mg} / \mathrm{l})\end{array}$ & [5] \\
\hline $\begin{array}{l}\text { Alkaline } \\
\text { hydrolyzate } \\
\text { of sewage sludge }\end{array}$ & $\begin{array}{l}\text { Proteins }(1.04 \mathrm{~g} / \mathrm{l}) \\
\text { and Carbohydrates } \\
(0.27 \mathrm{~g} / \mathrm{l})\end{array}$ & [6] \\
\hline Wheat straw & $\begin{array}{l}\text { Carbohydrates } \\
\text { (848.5 g/kg dry matter) }\end{array}$ & [7] \\
\hline Dairy wastewater & $\begin{array}{l}\text { Carbohydrates } \\
\text { ( } 26.0 \% \text { of dry matter), } \\
\text { Proteins ( } 25.4 \% \text {, of dry matter), } \\
\text { Fats ( } 26.0 \% \text { of dry matter) }\end{array}$ & [8] \\
\hline
\end{tabular}

sediments were stored at $4{ }^{\circ} \mathrm{C}$ until use. The $\mathrm{pH}$ value of the raw sludge was $6.9 \pm 0.1$ and the concentrations of suspended solids (SS) and volatile suspended solids (VSS) for the sludge used in the test were $7300 \pm 95 \mathrm{mg} / \mathrm{l}$ and $5050 \pm 61 \mathrm{mg} / \mathrm{l}$, respectively.

Because most hydrogen-producing microorganisms in excess sludge are spore-formers, the settled sludge was sterilized at $121{ }^{\circ} \mathrm{C}$ and $1.2 \mathrm{kfb} / \mathrm{cm}^{2}$ for $30 \mathrm{~min}$ in an autoclave (VARIOKLAV steam sterilizer, 300/400/500 EP) to inhibit or kill hydrogen-consuming microorganisms and select hydrogenproducers [10]. To remove the soluble organics from the seed microflora, the pre-treated sludge was centrifuged at $5000 \mathrm{rpm}$ for $10 \mathrm{~min}$ and then washed twice with sterile deionized water. The centrifuged sludge sediments were then used as the seed microflora for the biohydrogen production tests.

\subsection{Experimental procedures to evaluate biohydrogen production}

Batch tests of biohydrogen production were conducted in a series of $300 \mathrm{ml}$ reactors that were equipped with two ports for sampling gas and sludge. For each reactor, the seed microflora (about $5 \mathrm{ml}$ ), organic substrates (glucose or protein), $10 \mathrm{ml}$ of inorganic minerals solution and $135 \mathrm{ml}$ deionized water were added and mixed. The concentrations of the organic substrates in the mixtures are shown in Table 2. The concentrations of these organic materials were selected based on their contents in the organic wastes. No other organic materials were added to the reactors. As shown in Table 3, the components of the inorganic minerals solution were prepared according to the method described by Chen and Lin [11]. The SS and VSS of the mixtures added into the reactors were $5710 \mathrm{mg} / \mathrm{l}$ and $3740 \mathrm{mg} / \mathrm{l}$, respectively. To ensure that the original characteristics of the added organic materials were unchanged, the $\mathrm{pH}$ of the mixtures was not adjusted. The reactors were flushed with nitrogen gas for $30 \mathrm{~min}$ and then sealed prior to being placed in an air shaker (HKZ-C, China) at 140-150 rpm and $37 \pm 1{ }^{\circ} \mathrm{C}$. The tests were conducted in triplicate for each concentration and all results were the mean value of replicate analyses.

\subsection{Analytical methods}

Biogas production was measured periodically based on the displacement of saturated salt solution making corrections for atmospheric pressure and temperature [12]. The biogas in the headspace of the reactors was sampled with a 1-ml gastight syringe. Hydrogen production was calculated by measuring

Table 2 - The concentrations of organic materials in the mixtures of batch tests.

\begin{tabular}{lccc} 
No & Glucose $(\mathrm{mg} / \mathrm{l})$ & No & Protein $(\mathrm{mg} / \mathrm{l})$ \\
\hline C1 & 266.08 & P1 & 321.59 \\
C2 & 461.71 & P2 & 472.59 \\
C3 & 946.31 & P3 & 822.14 \\
C4 & 1603.65 & P4 & 1593.95 \\
C5 & 2443.17 & P5 & 2272.08 \\
C6 & 2985.65 & P6 & 2733.48 \\
\hline
\end{tabular}


Table 3 - Components of the inorganic minerals solution.

\begin{tabular}{lcll}
\hline Substance & $\begin{array}{c}\text { Concentration } \\
(\mathrm{g} / \mathrm{l})\end{array}$ & Substance & $\begin{array}{c}\text { Concentration } \\
(\mathrm{mg} / \mathrm{l})\end{array}$ \\
\hline $\mathrm{NaHCO}_{3}$ & 100.8 & $\mathrm{MnSO}_{4} \cdot 6 \mathrm{H}_{2} \mathrm{O}$ & 0.225 \\
$\mathrm{~K}_{2} \mathrm{HPO}_{4}$ & 1.875 & $\mathrm{CuSO}_{4} \cdot 5 \mathrm{H}_{2} \mathrm{O}$ & 0.075 \\
$\mathrm{MgCl}_{2} \cdot 6 \mathrm{H}_{2} \mathrm{O}$ & 1.5 & $\mathrm{CoCl}_{2} \cdot 5 \mathrm{H}_{2} \mathrm{O}$ & 0.001875 \\
$\mathrm{FeSO}_{4} \cdot 7 \mathrm{H}_{2} \mathrm{O}$ & 0.375 & & \\
\hline
\end{tabular}

the gas components and the total volumes of biogas produced. The contents of hydrogen in the biogas were analyzed using a gas chromatograph (GC122, China) equipped with a thermal conductivity detector (TCD). The contents of methane in the biogas were analyzed using a gas chromatograph (Agilent 6890 , USA) equipped with a flame ionization detector (FID).

The liquid was sampled with a $5-\mathrm{ml}$ gastight syringe. The concentrations of volatile fatty acids (VFA) and ethanol in the liquid phase were determined using another gas chromatograph (Shimadzu GC-9A, Japan) equipped with a flame ionization detector (FID). The concentrations of soluble protein in the liquor samples were measured by Lowry's method using bovine serum albumin as the standard solution [13], while those of glucose were determined by the phenol-sulfuric acid method using glucose as the standard solution [14]. The $\mathrm{pH}$ of the liquid samples was measured using a pH meter (PHS-3C, China). The biomass was measured by SS and VSS according to the standard methods [15]. Statistical analyses were conducted using SPSS 11.0 (SPSS Company, USA).

\subsection{DNA extraction, PCR amplification and DGGE analysis}

The sludge was sampled at the end of the anaerobic fermentation $\left(58^{\text {th }} \mathrm{h}\right)$, which was extracted the total community DNA as described by Zhang and Fang [16]. The DNA was then used as the template for polymerase chain reaction amplification denaturing gradient gel electrophoresis (PCR-DGGE) analysis.

The PCR primers F357GC (5'-CGCCCGCCGCGCGCGGCGGGCGGGGCGGGGGC ACGGGGGGCCTACGGGAGGCAGCAG-3') and R518 (5'- TTACCGCGGCTGCTGG -3') [17] were used to amplify a segment of the eubacterial 16S rDNA. A GC-clamp was added to the forward primers to facilitate DGGE. PCR amplification reaction was performed using a PTC-200 thermal cycler (BioRad Laboratories, USA) at a final volume of $50 \mu \mathrm{l}$ PCR. The reaction mixture contained $20 \mathrm{pmol}$ of both primers, $20 \mu \mathrm{mol}$ of each dNTPs, $5 \mu \mathrm{l}$ of $10 \times$ buffer, and 1.25 units of Taq DNA polymerase. The temperature cycling conditions were $94^{\circ} \mathrm{C}$ for $3 \mathrm{~min}$, followed by 31 cycles of $94{ }^{\circ} \mathrm{C}$ for $30 \mathrm{~s}, 55^{\circ} \mathrm{C}$ for $30 \mathrm{~s}$ and $72{ }^{\circ} \mathrm{C}$ for $1 \mathrm{~min}$. A final extension at $72{ }^{\circ} \mathrm{C}$ for $10 \mathrm{~min}$ was used. $5 \mu \mathrm{l}$ aliquot of the PCR product was separated on a $0.8 \%(\mathrm{w} / \mathrm{v})$ agarose gel at $100 \mathrm{~V}$ for $30 \mathrm{~min}$ to verify amplification prior to DGGE.

DGGE of the PCR amplified 16S rDNA was performed using a D-Code system (BioRad Laboratories, USA). The denaturing gradients used to separate the amplified 16S rDNA were $40-60 \%$. The gel was electrophoresed in $1 \times$ TAE buffer at $70 \mathrm{~V}$ and $60^{\circ} \mathrm{C}$ for $10 \mathrm{~h}$. The resulting gel was then visualized using Gel Red (Biotium USA). The analysis of the DGGE gel was conducted using the Bio-Rad software, Quantity One.

\section{Results and discussion \\ 3.1. Hydrogen fermentations of glucose and protein at neutral initial $\mathrm{pH}$}

Batch anaerobic fermentation tests of glucose and protein were conducted at neutral initial $\mathrm{pH}$ and without $\mathrm{pH}$ controlling to compare the biohydrogen production when each was used as the sole carbon source. As shown in Fig. 1, the accumulated hydrogen production of protein formed a parabola, whereas that of glucose produced a trapeziform curve. Many studies have reported similar results about biohydrogen production of glucose, other carbohydrates and carbohydrate - contained wastes [2]. Although the result of protein was similar with the study conducted by Bai [18] and Akutsu et al. [19] in which peptone was also used as the hydrogen-producing substrate, it was not inconsistent with the studies of our previous studies [6,9] and Guo et al. [5], in which sludge (a protein-contained waste) was used. The cumulative hydrogen production showed similar increases as the substrate increased, and the cumulative hydrogen production was much higher when glucose was used as the substrate than when protein was used. Indeed, the maximum cumulative hydrogen production was about $61 \mathrm{ml}$ when glucose was used as the substrate, while it was only $5 \mathrm{ml}$ when protein was used. Fig. 2 shows the hydrogen yields of unit organic substrates during the anaerobic fermentation. The changes of hydrogen yields were similar to that of the accumulated hydrogen production since the hydrogen yields of these organic substrates were calculated by dividing the cumulative hydrogen production by their initial quantity. Additionally, the hydrogen yields were nearly the same when there were high initial concentrations (namely, $>1603.65 \mathrm{mg} / \mathrm{l})$, and the maximum yield was about $0.14 \mathrm{ml} / \mathrm{mg}$ glucose $(1.1 \mathrm{~mol} / \mathrm{mol}$ glucose). Table 4 summarized some hydrogen yields in some studies. It could be found from Table 4 that the hydrogen yields of this study were similar with some previous studies and lower than some studies. The diversity may be caused by the diversity of the hydrogen-producing microorganisms, substance concentration, $\mathrm{pH}$, and so on, since these factors are important for biohydrogen production. The similar hydrogen yields observed when high initial glucose concentrations (>1603.65 mg/l) were used showed that the initial concentration had little impact on the biohydrogen yield when high concentrations were used in this test. The hydrogen yields produced when protein was used as the substrate were negatively correlated with its concentration, and the maximum (0.077 ml/mg protein) was observed at $321.59 \mathrm{mg} / \mathrm{l}$ (P1). Comparison the hydrogen yields from protein and proteincontained wastes (Table 4), it could be found that the hydrogen yields of protein observed in the present study were similar to the results of Bai $[18,19]$ and lowered some previous studies $[5,6]$. The diversity may also be caused by the hydrogenproducing microorganisms, substance concentration, $\mathrm{pH}$, and so on. Both the accumulated hydrogen production and hydrogen yields from protein were much lower than those observed when glucose was used as the carbon source, which suggested that protein was not good for biohydrogen produced by the anaerobic fermentation method used in the test. Additionally, since the optimal $\mathrm{pH}$ of biohydrogen production from 

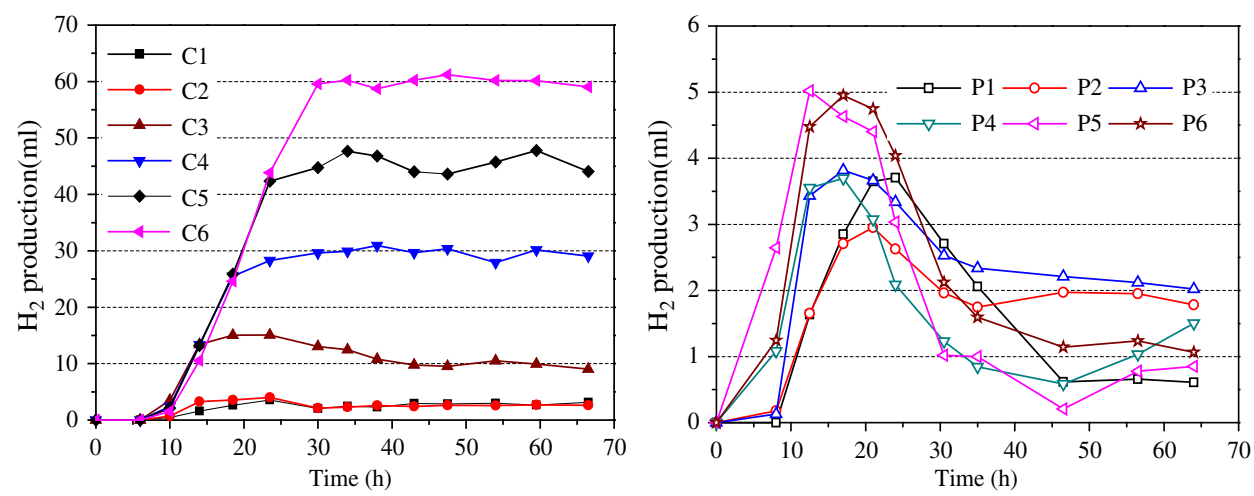

Fig. 1 - Accumulated hydrogen production during the anaerobic fermentation of glucose or protein.

carbohydrate (including glucose) and protein was acidic $\mathrm{pH}$ range and alkaline $\mathrm{pH}$ range, respectively, in order to produce maximally hydrogen from carbohydrate and protein, respectively, the fermentative $\mathrm{pH}$ should be in the optimal $\mathrm{pH}$ range.

Notably, there was a large difference in hydrogen consumption during biohydrogen production by the substrates evaluated here. Specifically, during the anaerobic fermentation of glucose, almost no hydrogen consumption was observed, especially at high initial concentrations. However, obvious hydrogen consumption occurred during the anaerobic fermentation of protein, and the hydrogen consumption almost began immediately after the cumulative hydrogen production reached its maximum (Figs. 1 and 2). In the anaerobic fermentation, glucose tend to be donated electrons (Eq. (1) and Eq. (2)), and the biodegradation of glucose can produce hydrogen [2]. Conversely, during the anaerobic fermentation of protein, some intermediates produced by the anaerobic degradation of protein, such as amino acids, could be reductive and act as an electron donor (e.g., glutamate, Eq. (3)), while some could be oxidative and act as an electron acceptor (e.g., proline, Eq. (4)) and others can act as both electron donors and acceptors (e.g., threonine, Eq. (5) and Eq. (6)) [23]. The electrons produced by oxidation of amino acids would be consumed by the reduction of others amino acids, thereby leading to few available electrons for the production of hydrogen via ferrodioxin and hydrogenase [24]. In other words, hydrogen may be produced and/or consumed during the anaerobic degradation of protein $[18,25]$. Additionally, initial $\mathrm{pH}$ is an important factor that influences hydrogen consumption in the anaerobic fermentation of protein. For example, Cai et al. [6] found hydrogen consumption existed at low initial $\mathrm{pH}(4-10.5)$ and not at high initial $\mathrm{pH}(>11.0)$ in the biohydrogen fermentation of alkaline pre-treated sludge. While in our previous study [9] few hydrogen consumption was observed in the anaerobic fermentation of the alkaline pre-treated sludge supernatant (which contained $2.14 \mathrm{~g}$ protein/l) at high initial $\mathrm{pH}$ value (>9.0).

$$
\begin{aligned}
& \mathrm{C}_{6} \mathrm{H}_{12} \mathrm{O}_{6}+2 \mathrm{H}_{2} \mathrm{O} \rightarrow 2 \mathrm{C}_{2} \mathrm{H}_{4} \mathrm{O}_{2}+2 \mathrm{CO}_{2}+4 \mathrm{H}_{2} \\
& \mathrm{C}_{6} \mathrm{H}_{12} \mathrm{O}_{6} \rightarrow \mathrm{C}_{4} \mathrm{H}_{8} \mathrm{O}_{2}+2 \mathrm{CO}_{2}+2 \mathrm{H}_{2} \\
& \mathrm{C}_{5} \mathrm{H}_{9} \mathrm{O}_{4} \mathrm{~N}+2 \mathrm{H}_{2} \mathrm{O} \rightarrow 2 \mathrm{C}_{2} \mathrm{H}_{4} \mathrm{O}_{2}+\mathrm{NH}_{3}+\mathrm{CO}_{2}+\mathrm{H}_{2} \\
& \mathrm{C}_{5} \mathrm{H}_{9} \mathrm{O}_{2} \mathrm{~N}+\mathrm{H}_{2} \mathrm{O}+\mathrm{H}_{2} \rightarrow \frac{1}{2} \mathrm{C}_{2} \mathrm{H}_{4} \mathrm{O}_{2}+\frac{1}{2} \mathrm{C}_{3} \mathrm{H}_{6} \mathrm{O}_{2}+\frac{1}{2} \mathrm{C}_{5} \mathrm{H}_{10} \mathrm{O}_{2}+\mathrm{NH}_{3} \\
& \mathrm{C}_{4} \mathrm{H}_{9} \mathrm{O}_{3} \mathrm{~N}+\mathrm{H}_{2} \mathrm{O} \rightarrow 2 \mathrm{C}_{3} \mathrm{H}_{6} \mathrm{O}_{2}+\mathrm{NH}_{3}+\mathrm{CO}_{2}+\mathrm{H}_{2} \\
& \mathrm{C}_{4} \mathrm{H}_{9} \mathrm{O}_{3} \mathrm{~N}+\mathrm{H}_{2} \rightarrow \mathrm{C}_{2} \mathrm{H}_{4} \mathrm{O}_{2}+\frac{1}{2} \mathrm{C}_{4} \mathrm{H}_{8} \mathrm{O}_{2}+\mathrm{NH}_{3}
\end{aligned}
$$

\subsection{Consumption of the two organic substrates and production of liquid organic by-products}

During the anaerobic fermentation, the glucose and protein were consumed by the microflora (Fig. 3A and B) and the liquid organic by-products (VFA and ethanol) were produced (Fig. 4).
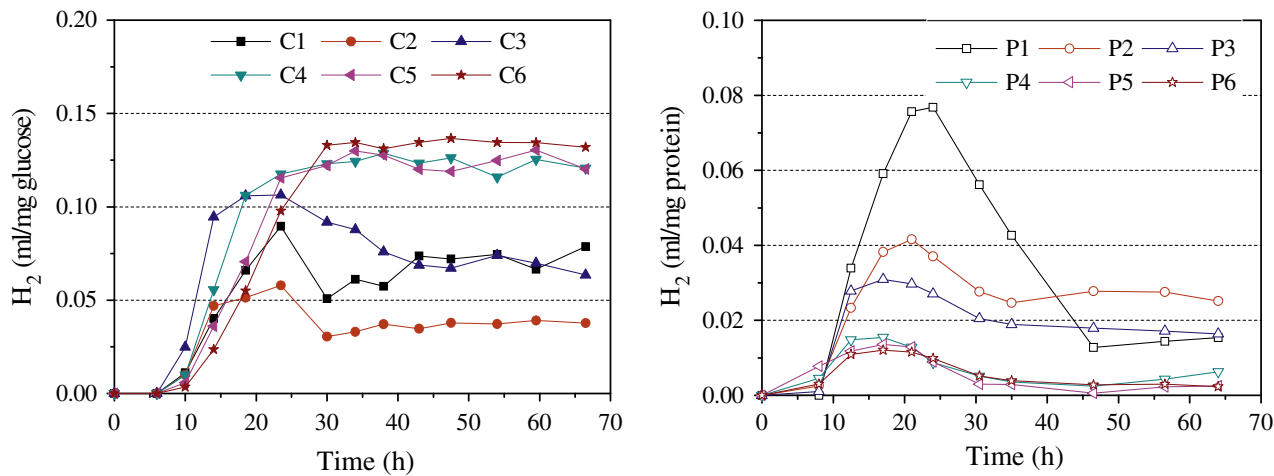

Fig. 2 - Biohydrogen yields from glucose or protein during the anaerobic fermentation. 
Table 4 - Comparison of hydrogen yield between this study and some previous studies.

\begin{tabular}{|c|c|c|c|c|c|c|}
\hline System & Inoculum & Substrate $(g / l)$ & $\begin{array}{c}\mathrm{pH} \\
\text { (initial pH) }\end{array}$ & $\begin{array}{c}\mathrm{T} \\
\left({ }^{\circ} \mathrm{C}\right)\end{array}$ & Hydrogen yield & Ref. \\
\hline Batch & Heat-treated anaerobic sludge & Glucose (2.82) & (6.2) & 25 & $0.968 \mathrm{~mol} / \mathrm{mol}$ & [20] \\
\hline Batch & Ethanoligenens harbinense B49 & Glucose (10) & (6.0) & 35 & $2.21 \mathrm{~mol} / \mathrm{mol}$ & [21] \\
\hline Batch & Heat-treated anaerobic sludge & Sucrose (24.8) & 5.5 & 34.8 & $3.4 \mathrm{~mol} / \mathrm{mol}$ & [22] \\
\hline EGSB & Mixed culture & Molasses $^{\mathrm{a}}$ & $4.2-4.4$ & 35 & $3.47 \mathrm{~mol} / \mathrm{mol}$ sucrose & [3] \\
\hline Batch & Heat-treated anaerobic sludge & Peptone $(5)^{b}$ & $(7.0)$ & 35 & $0.034 \mathrm{ml} \mathrm{H}_{2} / \mathrm{mg}$ protein & [18] \\
\hline Batch & Heat-pretreated natural microflora & Peptone $(5)^{\mathrm{b}}$ & (6.5) & 35 & $8.37 \mathrm{ml} / \mathrm{l}$ & [19] \\
\hline Batch & Alkaline pre-treated sludge & $\begin{array}{l}\text { Alkaline pre- } \\
\text { treated sludge }\end{array}$ & (11) & 36 & $16.6 \mathrm{ml} / \mathrm{g} \mathrm{DS}$ & [6] \\
\hline Batch & Pseudomonas sp. GZ1 & Sterilized sludge & (7.38) & 35 & $30.4 \mathrm{ml} / \mathrm{g}$ DS & [5] \\
\hline Batch & Sterilized sludge & Glucose (3.0) & (7.7) & 37 & $1.1 \mathrm{~mol} / \mathrm{mol}$ glucose & This study \\
\hline Batch & Sterilized sludge & Peptone (0.32) & (7.5) & 37 & $0.077 \mathrm{ml} \mathrm{H}_{2} / \mathrm{mg}$ protein & This study \\
\hline
\end{tabular}

For glucose, the substrate was rapidly consumed in the initial stage of fermentation, but little was consumed in the latter stage. Additionally, the rapid consumption stages were affected by the glucose concentration. Conversely, during the anaerobic fermentation of protein, the substrate was consumed throughout the fermentation period and the consumption in the initial stage of fermentation occurred more rapidly than in the latter stage. The consumption rates of these two organic substrates during the anaerobic fermentation were calculated in each sampling stage and the results are summarized in Fig. 3
(C and D). For the anaerobic fermentation of glucose, the maximal consumption rates occurred at the $10^{\text {th }} \mathrm{h}$ when low concentrations were used (C1-C3); therefore, 0-10 h was the maximal consumption stage. Conversely, the maximal consumption rate was observed at $23.5^{\text {th }} \mathrm{h}$ when higher concentrations were used (C4-C6); therefore, stage of 10-23.5 h was the maximal consumption stage. The trends in the consumption of glucose were similar to those of previous studies $[1,2,26]$. However, for the anaerobic fermentation of protein, the maximal consumption rates occurred at the $23.5^{\text {th }} \mathrm{h}$
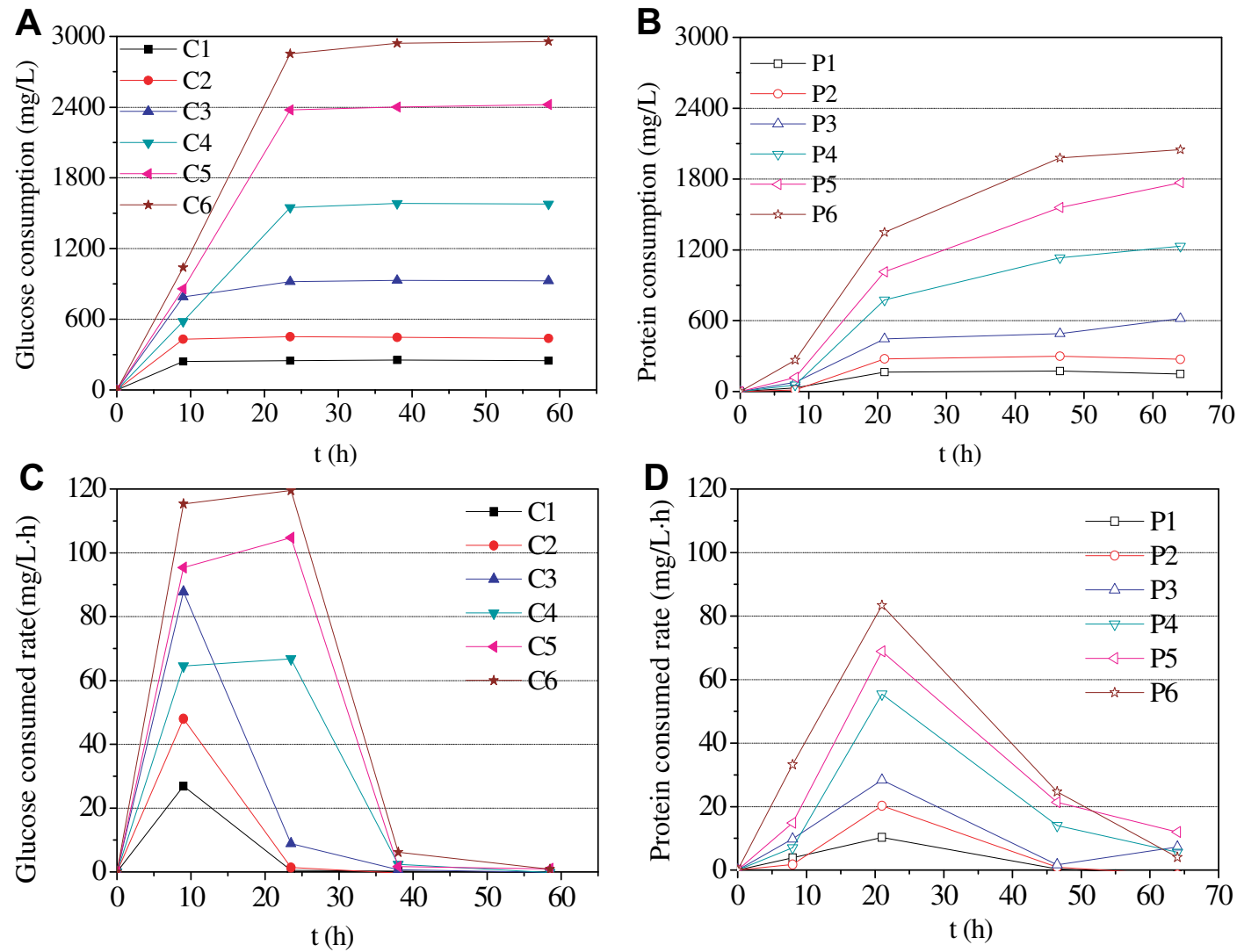

Fig. 3 - Consumption and consumed rate of glucose and protein during the anaerobic fermentation. 


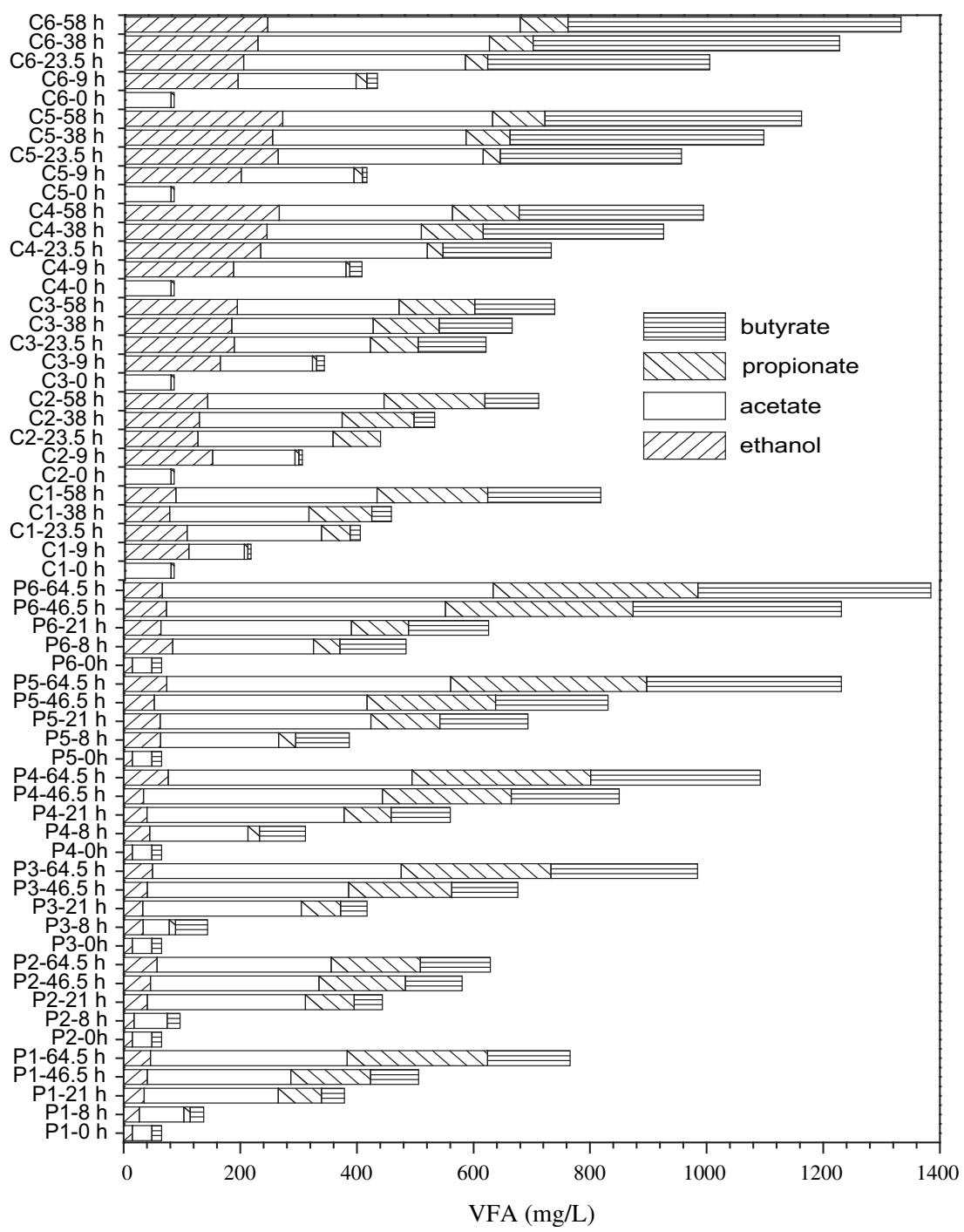

Fig. 4 - Changes of VFA and ethanol during the anaerobic fermentation.

for all tested concentrations. The above results suggested that the consumption of glucose was affected by its concentration and that of protein was not.

With the consumption of two substrates, the liquid organic by-products (VFA and ethanol) were produced and the yields were increased with the fermentation time and the concentrations of substrates (Fig. 4). The compositions of the liquid organic by-products for the two organic substrates differed. Specifically, the main compositions of the liquid organic byproducts for glucose were acetate, butyrate and ethanol and the content of propionate was lower, whereas those for protein were acetate, butyrate and propionate and the content of ethanol was lower. The different compositions of the liquid organic by-products illuminated that the hydrogen-producing pathways of the two substrates were different: the pathway of glucose was ethanol-type fermentation and that of protein was butyrate-type fermentation.

Comparing the three processes, consumption of two substrates, productions of hydrogen and liquid organic byproducts, it could be found that the production of liquid organic by-products was synchronous with the consumptioin of two substrates and the production of hydrogen was lag behind the other two processes. It is due to hydrogen-producing microorganisms in the seed microflora had to acclimatize the new environment. Analyzing the hydrogen yields of these two organic substrates during the anaerobic fermentation based on their initial concentration and consumption (Table 5), it could be revealed that the hydrogen yield was significantly correlated with their initial concentration and the consumption during the anaerobic fermentation. These results showed that the hydrogen produced during the anaerobic fermentation of the glucose and protein was actually produced by the degradation of these substrates.

\subsection{Changes of $\mathrm{pH}$}

The degradation of both glucose and protein produced several low weight molecular materials, such as $\mathrm{H}_{2}, \mathrm{CO}_{2}, \mathrm{H}_{2} \mathrm{O}$, VFA or amino acids, $\mathrm{NH}_{4}^{+}-\mathrm{N}$, and so on [1,2]. The production of VFA, amino acids and $\mathrm{NH}_{4}^{+}-\mathrm{N}$ could result in a change of $\mathrm{pH}$ 

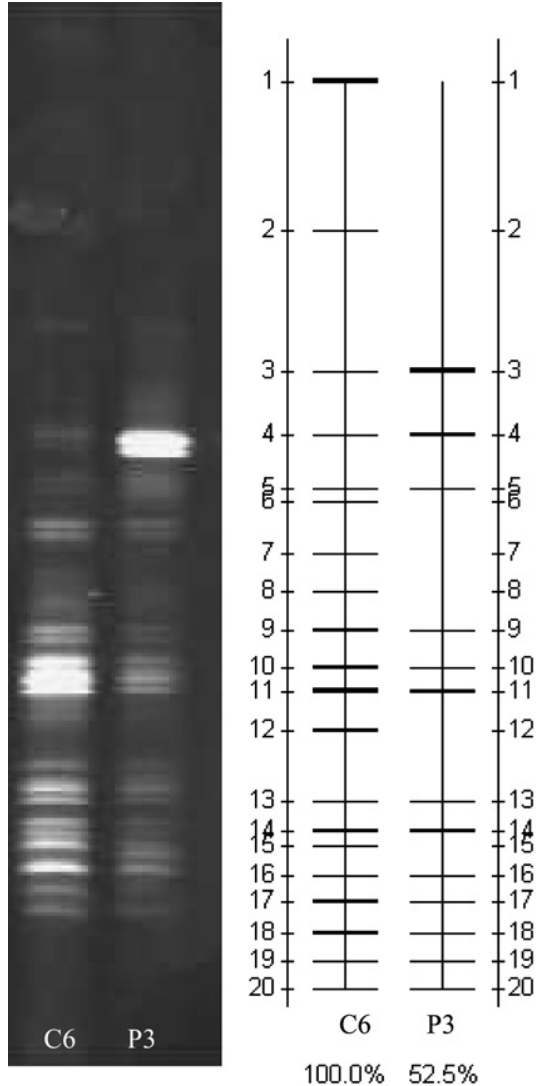

Fig. 6 - DGGE profiles of the microbial community produced by the anaerobic fermentation of glucose (C6) and protein (P3).

abundant microorganism may be a reason of lower hydrogen yield of this study.

\section{Conclusions}

The results of this study demonstrated that the maximal hydrogen yield of glucose at neutral initial $\mathrm{pH}$ was about $0.14 \mathrm{ml} \mathrm{H}_{2} / \mathrm{mg}$ glucose which was far higher than that of protein (about $0.077 \mathrm{ml} \mathrm{H}_{2} / \mathrm{mg}$ protein) in their anaerobic fermentation at neutral initial $\mathrm{pH}$. Unlike glucose, the hydrogen consumption could also be observed in the anaerobic fermentation of protein. Although, the hydrogen production was lag behind the consumption of two substrates and production of liquid organic by-products, statistical analysis revealed that the biohydrogen produced during the anaerobic fermentation of two substrates was significantly correlated with their degradation. In the anaerobic fermentation at neutral initial $\mathrm{pH}$, the hydrogen-producing pathways of two substrates were different: ethanol-type fermentation for glucose and butyrate-type fermentation for protein. In the anaerobic fermentation of protein, the $\mathrm{pH}$ maintained a stable $\mathrm{pH}$ near due the production of $\mathrm{NH}_{4}^{+}-\mathrm{N}$ and the amino acids. Finally, the molecular analysis indicated that the dominant microorganisms during the anaerobic fermentation of two substrates differed greatly.

\section{Acknowledgements}

The authors gratefully acknowledge financial support by the National Natural Science Foundation of China (Grant No. 50921064).

\section{R E F E R E N C E S}

[1] Das D, Veziroglu TN. Hydrogen production by biological processes: a survey of literature. Int J Hydrogen Energy 2001; 26:13-28.

[2] Hawkes FR, Dinsdale R, Hawkes DL, Hussy I. Sustainable fermentative hydrogen production: challenges for process optimization. Int J Hydrogen Energy 2002;27:1339-47.

[3] Guo WQ Ren NQ, Wang XJ, Xiang WS, Meng ZH, Ding J, et al. Biohydrogen production from ethanol-type fermentation of molasses in an expanded granular sludge bed (EGSB) reactor. Int J Hydrogen Energy 2008;33:4981-8.

[4] Mohan VS, Babu VL, Sarma PN. Effect of various pretreatment methods on anaerobic mixed microflora to enhance biohydrogen production utilizing dairy wastewater as substrate. Bioresource Technol 2008;99:59-67.

[5] Guo L, Li XM, Bo X, Yang Q, Zeng GM, Liao DX, et al. Impacts of sterilization, microwave and ultrasonication pretreatment on hydrogen producing using waste sludge. Bioresource Technol 2008;99:3651-8.

[6] Cai ML, Liu JX, Wei YS. Enhanced biohydrogen production from sewage sludge with alkaline pretreatment. Environ Sci Technol 2004;38:3195-202.

[7] Bauer A, Bösch P, Friedl A, Amon T. Analysis of methane potentials of steam-exploded wheat straw and estimation of energy yields of combined ethanol and methane production. J Biotechnol 2009;142:50-5.

[8] Vidal G, Carvalho A, Mendez R, Lema JM. Influence of the content in fats and protein on the anaerobic biodegradability of dairy wastewaters. Bioresource Technol 2000;74:231-9.

[9] Wei SZ, Xiao BY, Liu JX. Impacts of alkali and heat pretreatment on pathway of hydrogen production from sewage sludge. Chinese Sci Bull. Accepted.

[10] Wang CC, Chang CW, Chu CP, Lee DJ, Chang BV, Liao CS. Producing hydrogen from wastewater sludge by Clostridium bifermentans. J Biotechnol 2003;102:83-92.

[11] Chen CC, Lin CY. Start-up of anaerobic hydrogen producing reactors seeded with sewage sludge. Acta Biotechnol 2001;21: 371-9.

[12] Moosvi S, Madamwar D. An integrated process for the treatment of CETP wastewater using coagulation, anaerobic and aerobic process. Bioresource Technol 2007;98:3384-92.

[13] Lowry OH, Rosebrough NJ, Farr AL, Randall RJ. Protein measurement with the Folin phenol reagent. J Biol Chem 1951;193:265-75.

[14] Dubois M, Gilles KA, Hamilton JK, Rebers PA, Fred S. Colorimetric method for determination of sugars and related substances. Anal Chem 1956;28:350-6.

[15] APHA. Standard methods for the examination of water and wastewater. 20th ed. Washington DC, USA: American Public Health Association; 1998. pp. 2-53-2-59, 4-100-4-111.

[16] Zhang T, Fang HHP. Phylogenetic diversity of a SRB-rich marine biofilm. Appl Microbiol Biotechnol 2001;57: 437-40.

[17] Sánchez O, Gasol JM, Massana R, Mas J, Pedrós-Alió C. Comparison of different denaturing gradient gel electrophoresis primer sets for the study of marine 
bacterioplankton communities. Appl Environ Microbiol 2007; 73(18):5962-7.

[18] Bai MD. Study on characteristics of the hydrogen fermentation utilizing multiple substrates containing nitrogen compounds. Taiwan: NationalCheng Kung University; Ph.D. thesis; 2003.

[19] Akutsu Y, Lee DY, Li YY, Noike T. Hydrogen production potentials and fermentative characteristics of various substrates with different heat-pretreated natural microflora. Int J Hydrogen Energy 2009;34:5365-72.

[20] Oh SE, Van Ginkel S, Logan BE. The relative effectiveness of $\mathrm{pH}$ control and heat treatment for enhancing biohydrogen gas production. Environ Sci Technol 2003;37 (22):5186-90.

[21] Guo WQ, Ren NQ Wang XJ, Xiang WS, Ding J, You Y, et al. Optimization of culture conditions for hydrogen production by Ethanoligenens harbinense B49 using response surface methodology. Bioresource Technol 2009;100:1192-6.

[22] Mu Y, Wang G, Yu HQ. Response surface methodological analysis on biohydrogen production by enriched anaerobic cultures. Enzyme Microb Technol 2006;38(7): 905-13.
[23] Ramsay IR, Pullammanappallil PC. Protein degradation during anaerobic wastewater treatment: derivation of stoichiometry. Biodegradation 2001;12:247-57.

[24] Andressen JR, Bahl H, Gottschalk G. Introduction to physiology and biochemistry of the genus Clostridium. In: Minton NP, Clarke DJ, editors. Clostridia. New York, USA: Plenum Press; 1989. p. 27-62.

[25] Bai MD, Cheng SS, Chao YC. Effects of substrate components on hydrogen fermentation of multiple substrates. Water Sci Technol 2004;50:209-16.

[26] Chen W, Chen S, KhanalSK Sung S. Kinetic study of biological hydrogen production by anaerobic fermentation. Int J Hydrogen Energy 2006;31:2170-8.

[27] Baghchehsaraee B, Nakhla G, Karamanev D, Margaritis A, Reid G. The effect of heat pretreatment temperature on fermentative hydrogen production using mixed cultures. Int J Hydrogen Energy 2008;33:4064-73.

[28] Hafez H, Baghchehsaraee B, Nakhla G, Karamanev D, Margaritis A, Naggar HE. Comparative assessment of decoupling of biomass and hydraulic retention times in hydrogen production bioreactors. Int J Hydrogen Energy 2009;34:7603-11. 